\title{
Seja marginal, seja herói: a figura do herói e do anti-herói na obra de Hélio Oiticica ${ }^{1}$
}

\author{
Luiz Antonio Garcia Diniz ${ }^{2}$
}

\begin{abstract}
Resumo: Nossa proposta é abordar a obra do artista Hélio Oiticica, "Seja marginal, seja herói”, pelo viés de suas aberturas estruturais que articulam signos linguísticos e pictóricos. A ambiguidade e a polissemia de sua obra (1968) solicitam-nos, de um lado, a contextualizar o momento de sua produção histórica e, de outro, sua potencialidade transgressora, a qual transcende sua proposta, vinculada ideologicamente à postura daqueles que se posicionavam à margem, tanto da política oficial, quanto da cultura estabelecida.
\end{abstract}

Palavras-chave: Hélio Oiticica. Intersemiótica. Fotografia. Semiótica da imagem. Margens.

\section{Introdução: relações entre a imagem e o texto}

Acreditamos que nossa leitura da obra de Hélio Oiticica deva ser precedida por algumas considerações sobre o estatuto da fotografia como linguagem. Desse modo, é pertinente traçar alguns contornos sobre a reflexão da imagem na sua historicidade e, nesse recorte, a contribuição de Roland Barthes é fundamental. Assim, partimos da reflexão desse pensador para estabelecer alguns contrapontos ou diálogos entre determinadas posições relacionadas ao local que ocupa a imagem na contemporaneidade. Contrariamente à discussão que ainda persiste entre alguns segmentos acadêmicos sobre o estatuto da imagem em relação ao texto, mais precisamente, das especificidades que lhes são impostas, nossa proposta visa tratar esses dois conceitos como estruturas articuladas de signos que não fogem à codificação e à possível decodificação que tais estruturas oferecem ao olhar do leitor e, o que pode parecer paradoxal, em relação à imagem e à verbalização de suas semioses. Dito de outra forma, a reflexão sobre a imagem passa por sua estruturação em signos linguísticos, o que, de resto, estamos fazendo aqui. Desse ponto de vista, e para facilitar a nossa compreensão e utilização do termo "texto", o consideraremos como todo conjunto de articulação sígnica que possa ser "lido", "ouvido" ou "visto". Consideraremos, igualmente, que as passagens entre diferentes sistemas de

\footnotetext{
${ }^{1}$ Este estudo foi objeto de uma apresentação, em versão resumida, no I Congresso Internacional Texto-Imagem na UNIFESP (Guarulhos, 2010).

${ }^{2}$ Graduado em Ciências Políticas e Sociais pela Fundação Escola de Sociologia e Política de São Paulo, D.E.A. em Histoire de la Philosophie - Université de Paris IV (Paris-Sorbonne) (1982) e Doutor em Letras pela Universidade Estadual Paulista Júlio de Mesquita Filho (2008). Realizou um estágio no Canadá, em 2005/2006 (UQÀM/ÉAVM - École des Arts Visuels et Médiatiques). Atualmente, realiza Pós-doutorado, sob a supervisão do Prof. Dr. Adilson J. A. de Oliveira, no LAbI-UFSCar: Criação e recepção nas instalações interativas relacionadas às mídias digitais. Email: luizdiniz953@yahoo.fr.
} 
códigos que tais canais perceptivos e cognitivos permitem não são isoladas em blocos monolíticos, ao contrário, elas só podem existir quando os liames por elas estabelecidos sugerem significações propostas por suas estratégias discursivas, convergindo para o objeto tomado como referência analítica.

\section{Seja marginal, seja herói}

Assim, antes de adentrar na análise do objeto proposto, iremos esquematizar, metodologicamente, algumas definições da imagem como estrutura discursiva, logo, textual. Tal procedimento deve passar, em nosso modo de ver, pelo saber acumulado de pensadores que refletiram sobre a imagem, seu estatuto e sobre a sua característica ou não de signo. Roland Barthes, em sua obra $O$ óbvio e o obtuso (2009) situa, entre outros objetos de seu estudo, a imagem fotográfica na sua denotação, ou seja, na sua característica mais aparente de "cópia" da realidade, pela sua propriedade de imitar, de analogon e, na sua conotação, a saber, o segundo sentido provocado por ela, sobretudo quando se trata de imagens veiculadas pela imprensa ou pela publicidade. Assim, procederemos, mesmo que de forma simplificada, à esquematização de certo método analítico, ressaltando, porém, que se trata de apenas uma forma de entrada para a leitura e compreensão do objeto artístico. Imagem como imitação ou como simulacro de um referente?

Para tanto, resumiremos aqui as considerações de Barthes, no que se refere ao estatuto da imagem fotográfica. Tal viés analítico se justifica, pois falaremos de uma obra que reproduz uma imagem veiculada pela imprensa e que foi "alterada" no processo de conotação a que o artista se propôs na sua construção.

\section{Axiomas da mensagem fotográfica}

A fotografia da imprensa é uma mensagem constituída pela sua fonte emissora, o canal de recepção e, claro, pelo receptor, que é em primeira instância o objetivo do que consideramos como o início do processo de produção comunicacional:

1. Fonte emissora: a redação do jornal;

2. Canal de recepção: o próprio suporte de leitura, ou seja, o jornal; 
3. Receptor: o público ao qual a mensagem é destinada.

O autor considera, igualmente, que a fotografia de imprensa não é uma estrutura isolada, pois ela dialoga (no mínimo) com outra estrutura de códigos que é o texto, o qual pode vir a aparecer sob a forma de título, legenda ou artigo. O conjunto dessa estrutura informacional é, pois, construída por duas estruturas, uma linguística e outra imagética.

\section{O paradoxo fotográfico}

No que consistiria o conteúdo da mensagem fotográfica? Dito de outro modo, o que a fotografia transmite? O que ela tem a dizer? A princípio, uma fotografia mostra o que foi retratado por um meio mecânico - no caso da fotografia da qual estamos abordando, ou digital de captação do real, mesmo que esse real já seja em si um recorte de um real mais abrangente. Então, por consequência, o resultado do objeto fotografado se constituirá fatalmente, em si, em algo já diferente, tendo em vista sua manipulação provocada por diferenças cromáticas, trabalho de laboratório e, dependendo do caso, da iluminação, enfim, até de dados aleatórios que concorrem para o surgimento do objeto fotografado. Deve-se ressaltar aqui que, independentemente desses fatores e vista pelo senso comum, a fotografia é considerada um retrato do real, uma relação direta estabelecida com o referente.

Desse modo, podemos a priori admitir que a fotografia pode vir a ser considerada como uma mensagem sem código, o que significa, por sua vez, que a mensagem fotográfica é uma mensagem contínua.

Ainda, segundo Barthes, a fotografia não exige a recorrência a um recorte da sua unidade em signos que seriam transformados em código. Há de considerar, igualmente, que as duas mensagens (fotografias de imprensa e texto linguístico) ocupam o mesmo espaço em relação de contiguidade, porém, não de homogeneidade, significando que uma foto de imprensa não pode nunca existir sem outra mensagem que, no caso, é a escrita, sob pena de ficar à deriva do conjunto de significações e conotações que lhe seria atribuído. Em outras palavras, é necessário estabelecer uma ancoragem entre ela e o receptor e, desse modo, facilitar sua leitura.

\section{A fotografia manipulada, ou a passagem da imagem denotada para a conotada}


Além do conteúdo analógico, a cena, o objeto, ou o quer que seja que a fotografia represente, há ainda o que Barthes (2009, p. 15) considera o estilo de reprodução, algo já citado por nós anteriormente e brevemente (modificações técnicas operadas no objeto fotográfico), mas que justifica uma digressão, pois de tal procedimento deriva um segundo sentido cujo significante é a ação transformadora do criador, suas modificações na imagem e a direção imposta por ele ao objeto, dinâmica motivada por fatores estéticos ou ideológicos. Esse recorte feito previamente pela equipe de produção de imagem já determina o setor cultural receptor da mensagem. Esse procedimento procura demonstrar, grosso modo, que a fotografia é uma mensagem denotada e conotada, denotada porque, se de um lado, enquanto mensagem contínua ela é a cópia do referente, do analogon, de outro, ela é conotada pelo modo pelo qual a sociedade ou o receptor lê essa mensagem. Esse processo de denotação e de conotação é uma constante na mensagem fotográfica e, avancemos um pouco mais, ele se estende a todos os setores em que a produção de imagens investe para torná-las, senão cópias perfeitas da realidade, pelo menos seus simulacros.

Nessa trilha de raciocínio é oportuno lembrar Christian Metz (1973), o qual considera que a oposição analisada por alguns teóricos, quer dizer, uma separação categórica entre o analógico e o codificado não é um fato simples: o analógico para ele é também um meio de transferência de códigos. Assim, a afirmação já contestada por Barthes de que a fotografia é denotada porque se assemelha ao real, conforme popularmente é entendida, significaria abandonar os cruzamentos complexos de estruturas já conotadas e pertencentes à cultura a qual o objeto é situado. Além do mais, o próprio conceito de "semelhança" difere em sociedades temporal e culturalmente distintas. Ou seja, a "semelhança" não é percebida do mesmo modo, porque a semelhança é em si um signo conotado e pertencente, enquanto conceito cultural, a grupos sociais que podem divergir no tempo e no espaço. Ainda segundo Metz (1973, p. 20), "a partir do momento em que a cultura se apodera do texto icônico - e a cultura já está presente no espírito do criador de imagens -, ele, como todos os outros textos é oferecido à impressão da figura e do discurso".

Há, ainda, outro fator que consideramos relevante mencionar: todos os códigos, inclusive os visuais, são dificilmente passíveis de serem tomados isoladamente, pois estabelecem com outros, como por exemplo, o verbal, o sonoro, o tátil, entre outros -, relações de complexidade tal que dificultam os possíveis recortes que tenderíamos a 
estabelecer. A divisão categórica e redutora dos campos da linguagem em territórios definidos talvez seja o resultado de uma determinada prática acadêmica, a qual consiste na redução do conhecimento à área dos domínios de disciplinas, como a área da imagem, do código verbal, do fílmico e assim por diante. Christian Metz considera que a recorrência a esse tipo de prática só vem demonstrar o interesse de comodidades de trabalho, de setores de bibliografias que levam à "especialização" e, enfim, a competências determinadas e repassadas pelas instituições às quais os pesquisadores estão vinculados e, nesse sentido, para o autor, o domínio representaria simplesmente uma unidade pré-científica (METZ, 1973, p. 14).

Há, evidentemente, muitos outros elementos relacionados à reflexão sobre a imagem que deveriam constar aqui como, por exemplo, um aprofundamento maior acerca da retórica da imagem, dos processos de conotação tais como a trucagem, a pose, os objetos representados - lembrando que, com a tecnologia digital, a complexidade é ampliada -, a fotogenia, o esteticismo e a sintaxe. Enfim, há outros vetores de significação que adicionariam maior densidade à análise do nosso objeto, entretanto, o espaço para tal reflexão estenderia demasiadamente nosso artigo. Passaremos então à análise da construção da obra de Hélio Oiticica, nosso foco central de interesse.

\title{
Ascensão e descensão (Queda) do herói Cara de Cavalo
}

\author{
A imagem não é a imagem de um objeto, mas imagem do trabalho de \\ produção da imagem. \\ Jean-Louis Schefer
}

\section{Seja marginal, seja herói:}

\author{
(Figura 1)
}




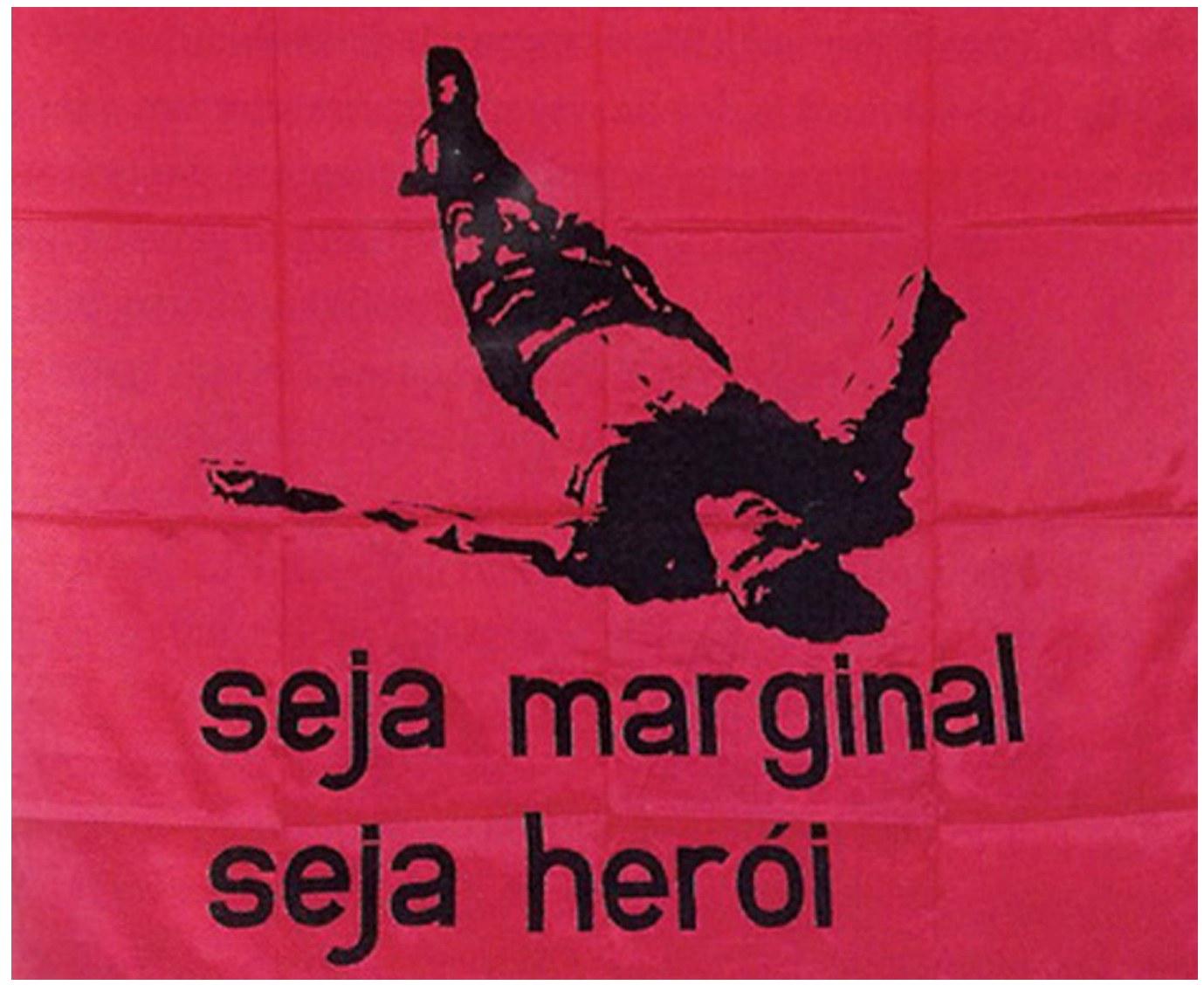

Fig. 1. Seja marginal, seja herói, Hélio Oiticica, 1968.

O trabalho de Oiticica consiste em uma peça semelhante a uma bandeira com o corpo de um bandido muito conhecido no Rio de Janeiro de então, serigrafado sob a forma de referência a Cara de Cavalo, morto pela polícia carioca. Como nesta obra em particular, não há referência linguística ao fato acontecido em 1964 - morte de Cara de Cavalo -, sua obra abre horizontes semióticos que podem ser recontextualizados para os dias atuais: qual a leitura possível desse trabalho? Acredito que uma releitura, entre outras que proporemos a seguir, seja a própria posição em que o artista ocupa na sociedade: marginal ou herói?

A contribuição da reflexão de Roland Barthes (2009) sobre as possíveis entradas em um texto é, para nós, seminal. Há a óbvia e a obtusa. Se partirmos da primeira como premissa, é o caso de lembrarmos os tempos da ditadura militar no Brasil, o esquadrão da morte e a repressão exercida em todos os segmentos da sociedade, com a ressalva e condição de que o leitor contemporâneo tenha conhecimento do momento de sua construção. Há, porém, outras instâncias de leitura propostas pelo objeto em questão, que nos remetem, no mínimo, a três entradas para a análise do objeto. A primeira é a acima citada, a questão ideológica e conjuntural; a segunda é a relação entre a imagem e o texto inscrito na própria obra; e a 
terceira é a retórica da imagem em si e a que ela estabelece com o texto. Talvez seja esta que nos incite a percorrer a obra não como a cristalização de uma produção de época, produto de uma conjuntura, mas como uma reflexão sobre a figura do herói e do anti-herói.

A figura dos "anti-heróis" ou "heróis anônimos" é recorrente na obra de Oiticica. É importante lembrar que ele procurou viver sua própria condição de artista-marginal no seio das contradições de uma sociedade que procurava claramente preservar determinados valores, conservando a política e a cultura consensuais, ou seja, uma sociedade calcada no valor da produtividade e da estabilidade. Basta lembrar as obras Cosmococa e os Parangolés, esta última consistindo no ato de libertar o "enquadramento" da cor do quadro, projetando-a e vestindo-a, literalmente, em corpos em movimento. Talvez seja desnecessário insistir no fato de que qualquer forma de produção artística que se coloca à margem do fluxo mercadológico e instrumental é predestinada a ser "apagada" da memória oficial. Desse modo, podemos afirmar que tanto o "bandido" Cara de Cavalo, como o "marginal" Oiticica sofreram das mesmas pressões e das punições reservadas aos outsiders.

A figura do cadáver do bandido Cara de Cavalo é espacializada em uma diagonal e recortada em um fundo vermelho vivo com os dizeres: seja marginal, seja herói. Nessa breve descrição da obra, já se coloca um elemento cultural que o leitor, dependendo do seu repertório cultural, poderá ou não proceder à identificação de determinadas estruturas referentes à pré-produção artística. Eis o motivo: não há em lugar algum no objeto artístico a menção linguística a Cara de Cavalo, a não ser em outra obra - mostrada abaixo, essa que tem por título Bólide 18, B-33 e que foi conhecida como Bólide em homenagem a Cara de Cavalo.

\section{Bólide}

\section{(Figura 2)}




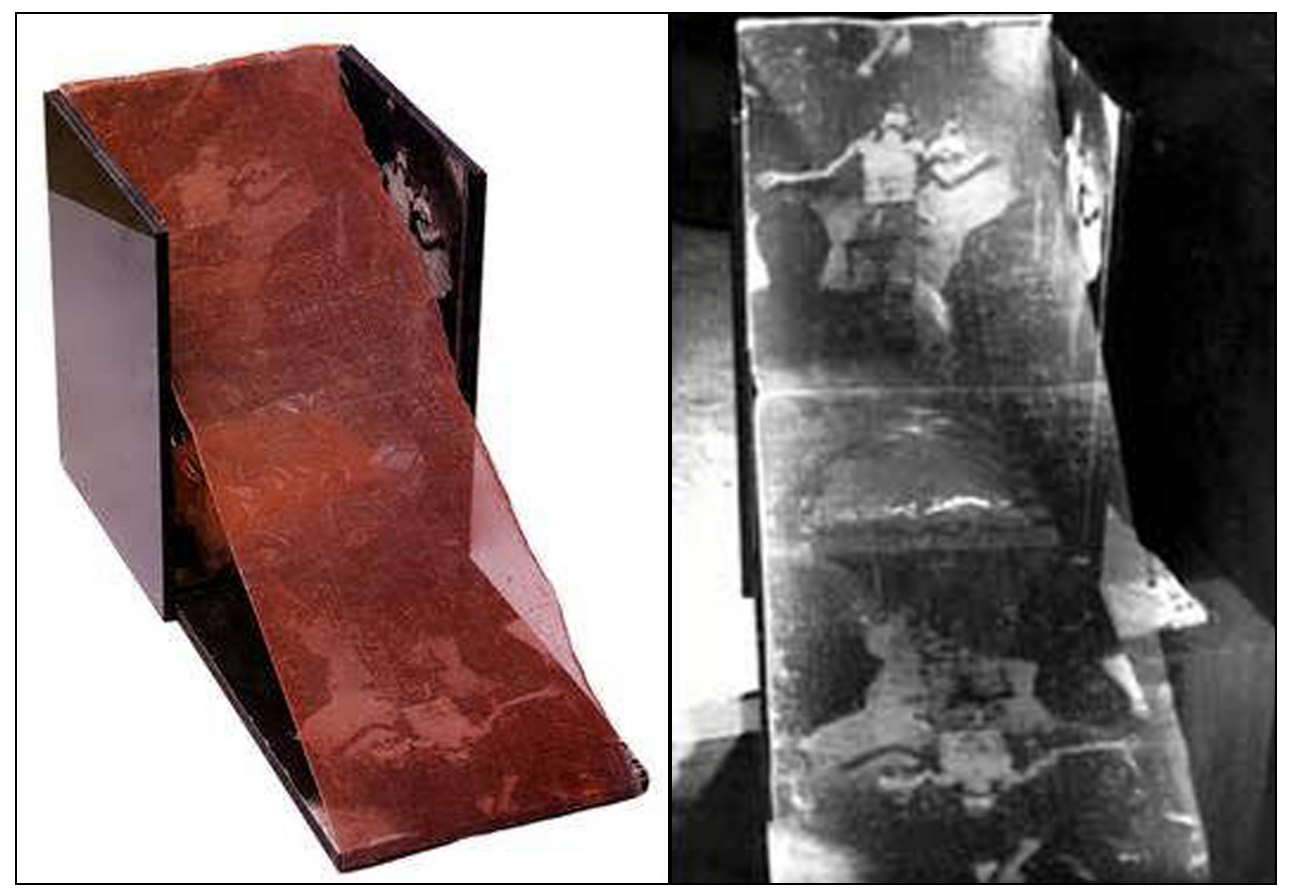

Fig. 2. Bólide 18, B-33.

A obra acima foi elaborada diferentemente do ponto de vista de sua espacialidade por se tratar de um objeto construído para ser disposto em uma superfície plana, como uma escultura. Já a obra analisada propõe uma mobilidade, solicita uma mão para segurá-la à semelhança de uma bandeira, banner ou estandarte. Na obra (Fig. 2), o título se refere a uma homenagem à figura representada, a mesma que foi usada para a "bandeira" que analisamos. Desse modo, com o apagamento do referente no objeto que analisamos, a ancoragem histórico-cultural $(1968=$ ditadura $=$ esquadrão da morte $=$ repressão $)$ deixa de ser índice absoluto para a análise da obra. Dessa maneira, a conotação possível, diretamente imposta e relacionada a essa ancoragem deixa de ser a única via de acesso à obra de Oiticica, pois a tensão estabelecida entre os dois textos (imagético e linguístico) libera o texto linguístico seja marginal, seja herói, de uma vinculação direta com o objeto imagético, deixando de atribuir, assim, valores ao marginal-referente Cara de Cavalo, enquanto elemento de resistência ao modo funcional da política brasileira da época.

Esse deslocamento metonímico foi necessário para, retoricamente, expulsar a figura do seu contexto original, deixando-a livre e aberta a conotações diversas. Nesse caso, e acredito que devemos enfatizar esse aspecto, com o apagamento do referente, a obra se abre para outras figuras históricas e conotações mais "universais", se é que tal conceito possa ser operacional. De qualquer modo, o olhar do receptor, desreferencializado pelas relações 
escópicas estabelecidas em diferentes patamares de conotação, amplifica e torna nosso objeto mais complexo. Aqui cabe uma referência à reflexão greimasiana (1993) sobre as isotopias temáticas e figurativas: as temáticas são abstratas e conceituais, já as figurativas são formas de ancoragem na narrativa dos conceitos enunciados por ela. Assim, na obra de Oiticica, as figuras do herói e do marginal, mesclam-se em uma posição de contiguidade, as quais para serem lidas são figurativizadas na figura do corpo, inicialmente referente do bandido Cara de cavalo, porém desreferencializada pela ausência de ancoragens vinculadas a tal figura, como as linguísticas ou outras quaisquer. O procedimento que vai do abstrato ao figurativo - não confundir a figurativização com figura, leva ao percurso generativo do enunciado por meio do qual o enunciatário será conduzido na leitura.

Porém, tendo em vista o, infelizmente, imenso arquivo imagético de guerras, de massacres étnicos e resultados de grupo de extermínio, pode-se afirmar que houve um deslocamento do símbolo Cara de Cavalo para instâncias externas e conotações complexas que pertencem ao universo da modernidade do século XX e XXI (Cf., por exemplo, os arquivos fotográficos dos campos de concentração). O texto, desse modo, desloca a possível identificação vinculada a um só indivíduo e a estende metonimicamente a um grupo de possíveis marginais, de possíveis heróis, de vítimas de guerra ou de anti-heróis anônimos. Outra figura de retórica que poderíamos sugerir nessa leitura - no caso do leitor possuir conhecimento do referente Cara de Cavalo -, poderia ser a extensão metafórica de sua figura, que viria cumprir aqui um papel na mise-en-scène estruturante da obra, como um Robin Hood dos morros, figura que nos anos 50 era muito conhecida nas favelas cariocas, como por exemplo, bandidos que roubavam caminhões de leite para distribuir às crianças famintas.

Outro fator relevante é a questão da narrativa. Poderíamos dizer que uma obra imagética narra? Qual a história contada? A narração de sua própria iconicidade dispensaria o recurso de outro código? Como a narrativa se estrutura em dois momentos distintos e simultâneos, a saber, o acontecimento e a causa, seria complexo atribuir à imagem fotográfica o acontecimento vinculado a uma causa exterior ao fato em si ou ao fato "re-presentado". A não ser que consideremos o fato de a narrativa se produzir dentro e fora da obra e, nesse caso, esta produziria indícios e o receptor ou destinatário da narrativa recomporia a narração de acordo com suas competências culturais. Essa questão foi levantada por Jacques Aumont no seu trabalho sobre cinema (2004, p. 139) em que discute sobre o que é, com efeito, uma narrativa. $\mathrm{Na}$ verdade, ela é essencialmente uma relação entre acontecimento e causalidade. 
Aproveitando tal questionamento, o trabalho de Oiticica fala do quê? Qual narrativa haverá no conjunto de seus indícios? Já avançamos em algumas possibilidades de leituras, lembrando, porém, que no caso da imagem cinematográfica e a imagem parada - fotografia em mídia de papel, por exemplo -, as formas narrativas se dão de modos diversos: na primeira, a causa é sempre imaginada (percebida) simultaneamente ao acontecimento, já na segunda, acreditamos que deveríamos nos projetar fora do tempo e espaço do vivido e nos levarmos pelos indícios construídos e conotados pelo produtor de imagem, para podermos, ao mesmo tempo, estar dentro e fora do acontecimento e da causa. Uma espécie de recuo e de avanço nas dimensões espaciais e temporais que precedem a estruturação do objeto e seu acontecimento temporal.

\section{Mise-en-scène ou possíveis estratégias discursivas}

Ainda no campo da encenação artística, chamaríamos a atenção para a posição escolhida pelo artista para a espacialização do cadáver: ele sugere, quase que miticamente, um ser sacrificado em um ritual religioso, uma descensão ou queda de instâncias pelas quais sua figura foi brutalmente arrancada. A dramaticidade é aumentada pela escolha das cores empregadas, o vermelho vivo e o negro, cores fortes e geralmente escolhidas pela imprensa para destacar tragédias. Vale lembrar que tais cores são igualmente recorrentes nas produções cinematográficas, publicitárias, nos cartazes da revolução russa e em obras literárias, como o Le rouge et le noir, de Stendhal, romance de 1830 - no caso, o vermelho como símbolo da carreira militar e o negro como escolha religiosa, cor da roupa utilizada pelos religiosos. São ancoragens figurativizadas empregadas para situar a divisão a qual o personagem do romance, Julien Sorel, estava submetido naquele contexto histórico.

Assim, essas cores se colocam, antes de tudo, como símbolos conotados por uma história de significações já incorporadas na cultura ocidental e vêm cumprir o papel de indícios, de âncoras, de semioses e, sobretudo, conduzem o leitor nas possíveis leituras que o texto lhe propõe.

Voltando à nossa proposta da leitura da posição ocupada pela figura central do objeto que analisamos, tomamos a liberdade de recorrer a um pequeno exercício para exemplificar a escolha de Oiticica na estruturação do objeto.

Essa escolha da "descida" carregada de dramaticidade poderia ser invertida e, aqui, nos permitiremos uma pequena modificação da obra de Oiticica, com o intuito de mostrar que 
uma simples substituição da figura sob a forma de "ascensão" mudaria completamente a direção de nossa leitura, conforme nos mostra a figura abaixo:

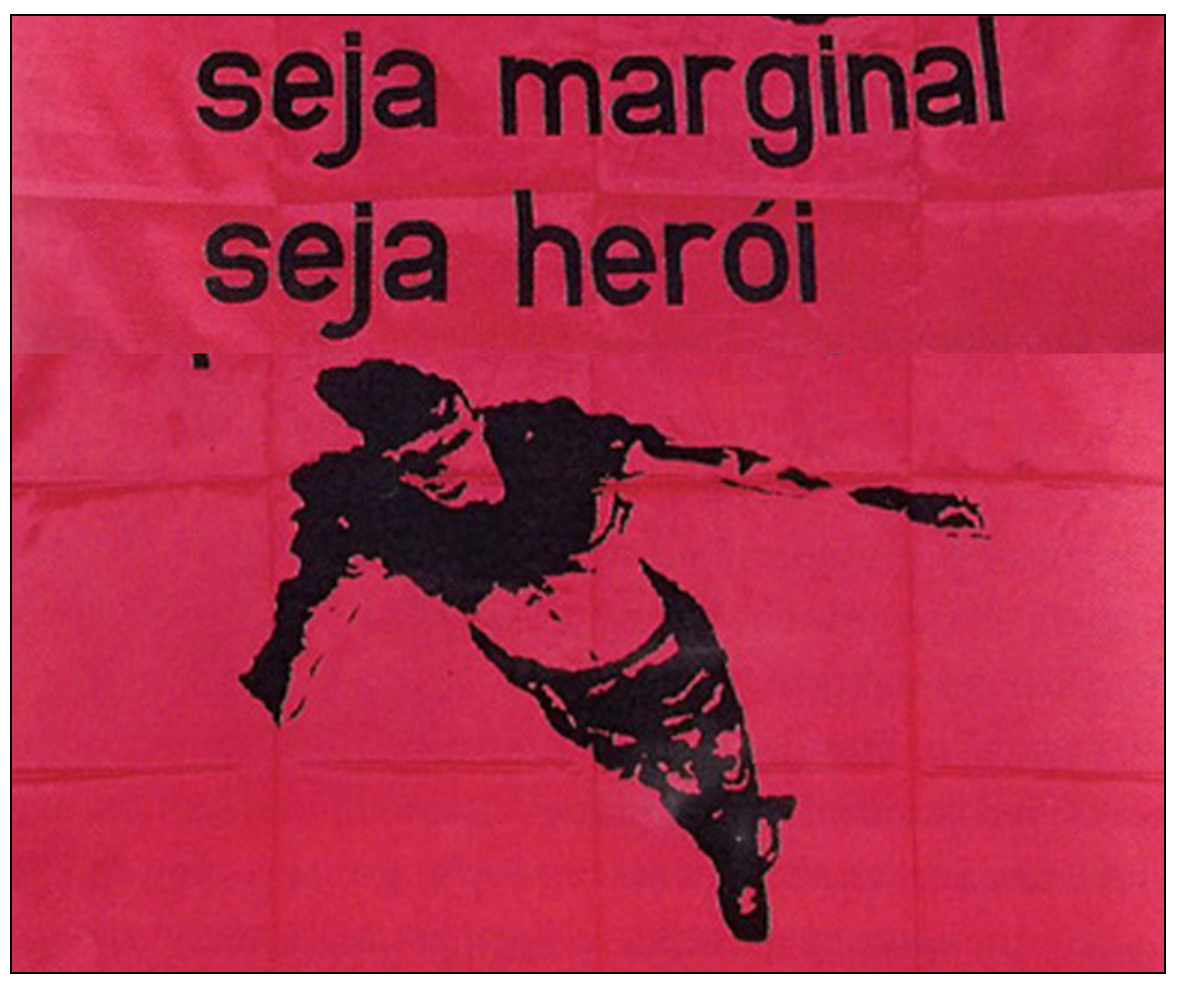

Fig.3 (modificação da obra de Oiticica a fins puramente analíticos)

O corpo, nessa inversão, produz a sensação de ascensão a algo mítico, uma catarse redentora e invocativa, não ingenuamente, de mitos religiosos e algo que virá "depois". Depois da morte, do exemplo paradigmático, da rejeição social da situação que a figura significa ou, ainda, de outras formas de "possíveis" - processo sempre posterior ao acontecimento -, tomadas, porém, no sentido de apaziguamento, instância da catarse clássica. A imagem original, ao contrário, não busca amenidade ou redenção - não há outra forma possível de representar sua inexorável tragédia.

Oiticica, em uma carta a Frederico Morais (1968), explica o que o levou à construção das obras em homenagem a Cara de Cavalo: "foi um momento ético". Cabe a nós - o leitor ou receptor - recortar, na cultura brasileira e na historicidade da feitura da obra, o que o levou a esse "momento ético". Digamos que o projeto "utópico" do artista era unir o morro à cidade, daí sua relação próxima com a Mangueira, tanto do morro e seus personagens, quanto da escola de samba que o representa, cenário situado na abrangência que sustenta seu ponto de vista político-cultural. 
Aqui caberia, certamente, lembrar a barbárie da polícia carioca, dois mil homens mobilizados para a caça ao inimigo público número um, com todos os requintes de crueldade possível: foram encontrados no seu corpo, aproximadamente cem projéteis e, na verdade, Cara de Cavalo era um bandido "menor", cujo delito maior - no entanto mítico - foi o de matar o detetive LeCoq, participante do esquadrão da morte.

Retomando o ético tal como o descreve Oiticica, podemos conceber que tal ritualismo midiático transformado em espetáculo - não sem lembrar Guy Debord (1931-1994) ${ }^{3}$-, vem corroborar a reflexão de Seligmann (2000), que questiona os valores universais que vão desde a tragédia grega até à literatura moderna tomada como espaço de encenações e, re-situa a questão do universal e do ético: se para Shelling (1775-1854), o artista era mediador do universal, é que ainda havia uma sustentação histórico-cultural para tal conceituação; hoje, no entanto, com o colapso das figuras universais pertencentes ao universo da modernidade utópica, o campo do estético não pode ser concebido como independente, isoladamente ou à margem do ético. Ainda na trilha do leque de possibilidades da leitura da imagem na sua relação com o texto, há na reflexão de Márcio Seligmann (2000), no artigo citado, a noção de trauma, de catarse e de recalque na produção artística contemporânea. Reflexão brilhante conduzida pelo viés psicanalítico, porém, não restrito somente a ele e que contribui enormemente na leitura de obras como a de Oiticica. Particularmente, em relação ao Brasil da época da realização do objeto analisado, o trauma histórico-social e não mais individual corresponde ao período da ditadura, em relação direta com movimentos de resistência, tanto políticos quanto culturais. Para se restringir a dois, a saber, as artes das chamadas vanguardas cujo expoente importante da cultura Pop foi o Tropicalismo e a luta armada, a figura representada no tecido indicaria como possível leitura - dependendo da vinculação aos dois movimentos acima citados -, tanto o artista que se situava fora da cultura do permitido, quanto o político engajado, comumente preso, torturado, que geralmente "desaparecia" ou era "encontrado" morto em algum terreno abandonado ou ainda, nunca mais encontrado.

Vale lembrar que em 1968, quando os cantores e compositores Caetano Veloso e Gilberto Gil foram presos na boate Sucata no Rio de Janeiro, a obra de Oiticica fazia parte dos elementos cênicos.

Alguns dos aspectos já mencionados são encontrados em dada vertente da arte contemporânea, na medida em que ela se mostra mais como uma "presentação" do real do que

\footnotetext{
${ }^{3}$ Disponível em: http://www.ebooksbrasil.org/eLibris/socespetaculo.html.
} 
o de sua representação pelas formas "imitativas" ou "realistas". Ela se dá a ver mais pela tentativa de escapar dos recursos estratégicos da identificação e da catarse clássica, para tornar-se, desse modo, uma mise-en-scène das formas estéticas daquilo que escapa aos valores de reprodução econômica ou de objeto aurático, nos termos benjaminianos.

À guisa de conclusão, podemos considerar que a questão axiomática continua a mesma, a saber, a imagem como analogon - ainda que analógica e não passível de ser divida em unidades sinaléticas codificadas e transformadas em signos - adquiriu por meio de sua retórica maior porosidade em relação a sua leitura: mensagem contínua, porém, conotada pela cadeia de significações que a cultura engendra. Acreditamos ainda necessário assinalar a existência de códigos intermediários entre o imagético e o linguístico: Massironi (1983, p. 117) considera que se a linguagem é operada por conceitos (códigos) e a percepção - pelo menos a visual, pois há a auditiva e a tátil - por objetos. Há certamente uma zona de fronteira em que esses dois modos operatórios se encontram: o espaço de convergência e de contaminação dos ideogramas e da pictografia.

O texto pode ser icônico e a imagem "falante" ou verbalizante, as geometrias de Mondrian, por exemplo, sugerem códigos, unidades dimensionais que seguem uma rigorosa sintaxe. Os campos tensionais impostos pela imagem e pelo texto verbal ora se sobrepõem, ora se separam, levando-nos à elaboração de textos codificados a partir da imagem e à criação de imagens a partir da codificação linguística, por conta do vetor de iconicidade que o texto transmite por meio de descrições de espaços imagéticos, sonoros e arquitetônicos, entre outros.

Se a imagem simulada do cadáver, no objeto de nosso estudo, indica uma presença ausente, a reflexão de Baudrillard, em sua obra Simulacros e simulações (1991), passa a ser pertinente em nossa análise, pois se não há mais real, tal qual ele foi conceituado no século XX, o simulacro ou sua simulação poderia ter o sentido ou o papel, dentre outros, de questionar a veracidade do referente. Daí podermos inferir de nossa reflexão a seguinte interrogação: se não há mais referentes, aquém ou além dos simulacros e simulações, o que restará na nossa sociedade contemporânea, além de um discurso contínuo articulado por signos?

\section{Referências bibliográficas:}


AUMONT, Jacques. O olho interminável: cinema e pintura. São Paulo: Cosac \& Naify, 2004.

BARTHES, Roland. O óbvio e o obtuso. Lisboa: Edições 70, 2009.

BAUDRILLARD, Jean. Simulacros e simulações. Lisboa: Relógio D’água, 1991.

GREIMAS, Algirdas J.; COURTÈS, Joseph. Sémiotique; dictionnaire raisonné de la théorie du langage. Paris: Hachette, 1993.

MASSIRONI, Manfredo. Ver pelo desenho: aspectos técnicos, cognitivos, comunicativos. Lisboa: Edições 70, 1983.

METZ, Christian (Org.). A análise das imagens. Petrópolis, RJ: Vozes, 1973.

OITICICA, Hélio. Itaú Cultural: Programa Hélio Oiticica. Carta a Frederico Morais, 1968. Seleção de textos do artista disponibilizados online. http://www.itaucultural.org.br/aplicexternas/enciclopedia/ho/index.cfm?fuseaction=document $\underline{\text { os } \& \operatorname{cod}=145 \& \text { tipo }=2}$

SCHEFER, Jean-Louis. A imagem: o sentido "investido". In: METZ, Christian (Org.). A análise das imagens. Petrópolis, RJ: Vozes, 1973.

SELIGMANN-SILVA, Márcio. A história como trauma. In: SELIGMANN-SILVA, Márcio \& NESTROVSKI, Arthur (Orgs.). Catástrofe e representação. São Paulo: Escuta, 2000.

Be a marginal, be a hero: the figure of the hero and the anti-hero in Hélio Oiticica's works

\begin{abstract}
We propose to reflect on the work "Be marginal, be a hero", by Hélio Oiticica, through his structural overtures and that articulate linguistic and pictorial signs. The ambiguity and multiple meanings of his work (1968) demand from us, on the one hand, contextualizing the historical time of this production and, on the other, of its transgressing potential, which transcends its proposal related to the ideological position of those who place themselves apart from the margins, both from official politics and from the established culture.
\end{abstract}

Key words: Hélio Oiticica. Intersemiotics. Photography. Semiotics of the image. Margins. 